\title{
ENHANCING THE TOURIST ATTRACTION VISITING PROCESS WITH GAMIFICATION: KEY CONCEPTS
}

\author{
JAKUB SWACHA, ROBERT ITTERMANN
}

\begin{abstract}
A B S T R A C T
The main purpose of this paper is to describe key gamification techniques that can be applied to enhance the tourist attraction visiting process. The paper is based on the methodology of design patterns; particularly it adopts the definition and classification schemes originally proposed and developed in the context of gamification of work to specify gamification techniques related to various aspects of the tourist attraction visiting process. The main result is the selection of twelve gamification techniques for enhancing the tourist attraction visiting process, four for each of the three phases of the visiting process (before, during and after the visit). The paper shows that gamification techniques can be applied to enhance the tourist attraction visiting process. Implementation of the proposed gamification techniques is supposed to both improve visitor experience and give the tourist attraction managers a tool for boosting interest in less popular exhibitions and events.
\end{abstract}

KEY WORDS

tourism gamification, visitors' experience, tourist attraction management

DOI: 10.1515/emj-2017-0031
Corresponding author:

Jakub Swacha

University of Szczecin, Faculty of Economics and Management, Institute of Information Technology in Management, Poland e-mail: jakubs@uoo.univ.szczecin.pl

Robert Ittermann

Business Academy North, Project Management, Germany e-mail: ittermann@ wirtschaftsakademie-nord.de

\section{INTRODUCTION}

While the tourist attraction management must consider various aspects of the attraction's operation such as administration, maintenance and development, education and communication, or marketing and public relations, the visiting process should always be its primary concern as it shapes the tourist experience. When executed correctly, it leaves a good impression even from a visit to a dull site; if faulty, it can turn a visit to a world-class attraction into a negative experience.

In this paper, the possibility of enhancing the visiting process with gamification techniques is considered. The objectives of the paper are to identify and classify problematic situations, to define remedies 
to counter them, and to assign appropriate gamification techniques that support these remedies.

The paper starts, however, with an explanation of basics of gamification based on the literature. The chosen design approach is presented in section 2, whereas sections 3-5 form the core of the paper, as they describe the gamification techniques applicable respectively to the three phases of the visiting process. The final section presents conclusions.

\section{LITERATURE REVIEW}

Gamification describes the idea of using particular elements of games in contexts outside that field to make them more interesting or to raise the customer's motivation (Deterding et al., 2011, pp. 9-10). The term "gamification" was initially coined in 2002 (Pelling, 2011) and has gradually been adopted in research and practice since 2010 (Deterding et al., 2011, p. 9). That year, at the TED Innovations Conference in Monterey, game designer Jane McGonigal gave a pioneering lecture in which she clarified "that gamers are a human resource that we can use to do real-world work, that games are a powerful platform for change. We have all these amazing superpowers: blissful productivity, the ability to weave a tight social fabric, this feeling of urgent optimism and the desire for epic meaning" (McGonigal, 2010, pp. 18-51).

Since 2010, hype about the topic of gamification has emerged, fuelled by marketing experts who saw great opportunities regarding more efficient relations with the customers. Consequently, numerous gamified systems were developed and implemented in various areas (for example education, trading, tourism, and health).

There were some factors behind the success and the increasing adoption of gamification. Video games and the use of playful elements (online as well as offline) became increasingly accepted culturally. Furthermore, the acceptance of customers towards dealing with gamified systems increased as well (Shauchenka, Ternès \& Towers, 2014, p. 33). The most important factor, however, was the technological progress and falling manufacturing costs for technological products (such as smartphones) which it caused. As a result, technologically-mediated gamification could be made accessible to a larger target group (Sailer, 2016, pp. 5-6).

Gamification is a relatively new term for an old phenomenon. The basic idea of using playful ele- ments outside the field of games is neither new nor limited to modern media. For instance, the military has been using games and simulations in drills for centuries. The same is true for badges to distinguish different ranks (Zichermann \& Cunningham, 2011, p. 9). A similar ranking system has been used by the scout-movement since 1910. Members receive badges for new experiences, learned skills or performed services. The worldwide fast food franchise McDonald's had used game mechanics for its business long before the term gamification was coined: the popular McDonald's monopoly board was created already in 1987 (Amadou, 2011).

\subsection{Definitions}

Currently, there are many definitions of the term gamification used in the literature. Three most popular will be introduced briefly. Zichermann and Cunningham (2011) define the term gamification as "the process of game-thinking and game mechanics to engage users and solve problems" (pp. 14-15). Thus, gamification makes use of game mechanics to motivate consumers more, to solve certain problems and to design the necessary tasks in a more interesting way (Zichermann \& Cunningham, 2011, pp. 14-16). According to Kapp, Blair and Mesch (2014) gamification consists of three components: "Gamification is using game-based mechanics, aesthetics, and game-thinking to engage people, motivate action, promote learning, and solve problems" (p. 86). The "game-thinking" expression follows from the idea that every daily action also offers some playful potential, through which it can be made more interesting. However, there are critical views on these definitions since both limit the reach of gamification by naming precise goals (Sailer, 2016, p. 8). For this reason, a relatively simple and merely limiting definition was established in a scientific discourse (Ruffino, 2014, p. 50). It can be traced back to Deterding et al. (2011), who describe gamification as "the use of game design elements in non-game contexts" (p. 10). This definition consists of four elements that are explained briefly below.

Game. To begin with, the terms "game" and "play" are to be distinguished from one another in the context of gamification. For this purpose, a model by Roger Caillois (1961) can be used (Salen \& Zimmermann, 2004, pp. 308-309). He assigned several playful activities to either the concept of ludus or to the concept of paidia. The term paidia in this respect describes an unregulated and spontaneous 
joy about an activity. The counterpart to this is described through the term ludus, which describes a disciplined and strongly regulated playful activity (Caillois, 1961, p. 26). In the context of gamification, ludus denotes the concept of games, in which certain rules and clearly defined goals are in the foreground. Consequently, they do not solely serve the purpose of entertainment, but they do have an additional and higher meaning. Paidia can be understood in the sense of play and describes a free, improvised behaviour without a particular structure, serving only the purpose of entertainment. As the name gamification suggests, gamified solutions are to be assigned mainly to the ludus side. This, however, does not exclude the paidia side (Sailer, 2016, pp. 9-12).

Elements. To specify the characteristics of a game element, the concepts of gamification and serious games can be opposed to one another. Serious games can also be assigned to the ludus side. Following this concept, the consumer is meant to reach a higher goal through a playful process (for example learning). What the concepts of gamification and serious games have in common is that they aim at non-entertainment goals by means of a controlled process (Sailer, 2016, pp. 12-13). The difference, however, is that serious games are understood as fully-fledged games, while the concept of gamification only refers to the use of typical elements of games. Yet, the line between game elements and the fully-fledged game is sometimes quite blurry and often influenced by individual views.

Non-game context. The definition of gamification excludes the gamification of games. This process would not be a gamification, but merely an extension of the game content and, therefore, a part of game design (Shauchenka et al., 2014, p. 35). In this respect, it does not matter whether a classic board game, a card game or a video game is affected. Thus, it is not the content that is of relevance, but the context (Rackwitz, 2015, p. 219).

Gamification aims at enhancing miscellaneous non-game contexts by means of game design elements (Deterding et al., 2011, pp. 12-13). Normally, these elements serve the purpose of entertaining the player. In the concept of gamification, however, game design elements are mainly used to reach different goals, for example to amplify motivation, engagement and participation of the consumer or to support learning and interaction (Sailer, 2016, p. 14).

Design. The term design in the context of gamification can theoretically refer to game elements (typical and characteristic components of games) or game-based technologies (for example game controllers, 3D graphics engines, authoring tools). Deterding et al. (2011) suggest using the term gamification exclusively relating to typical game design, and to illustrate this, consequently use the term game design element (instead of gamification design element). Yet, compared to fully-fledged games, only several game design elements are purposefully used in a gamified application.

Deterding et al. (2011) managed to identify these game design elements on five different levels of abstraction, which are subsequently displayed and described in Tab. 1. To provide a more intelligible description of the individual levels of abstraction, descriptions by Morschheuser (2013) were used as well.

Tab. 1. Abstraction levels of game design elements

\begin{tabular}{|l|l|}
\hline \multicolumn{1}{|c|}{ LEVEL OF ABSTRACTION } & \multicolumn{1}{c|}{ DESCRIPTION } \\
\hline $\begin{array}{l}\text { Game interface design } \\
\text { patterns }\end{array}$ & $\begin{array}{l}\text { Interface-elements are located on the level best visible to the user. Those are known from video games. } \\
\text { Some of them are for example progress bars, points, badges, leaderboards, ranks or levels }\end{array}$ \\
\hline $\begin{array}{l}\text { Game design patterns } \\
\text { and mechanics }\end{array}$ & $\begin{array}{l}\text { The second level determines the functionality of the interface elements (for example time constraint, } \\
\text { limited resources) and thus influences the way in which the game is experienced (for example fun } \\
\text { or experiences) }\end{array}$ \\
\hline $\begin{array}{l}\text { Game design principles } \\
\text { and heuristics }\end{array}$ & $\begin{array}{l}\text { They prescribe the framework or the core for the implementation of gamification. In this respect, } \\
\text { psychological aspects are considered (for example clear goals or a variety of game styles). } \\
\text { The principles of game design are crucial to the generation of motivation }\end{array}$ \\
\hline Game models & $\begin{array}{l}\text { On this level, the correct usage of interface elements and game design mechanisms are justified. } \\
\text { These models are described as "conceptual models of the components of games or game experience" } \\
\text { (Deterding et al., 2011, p. 12) }\end{array}$ \\
\hline Game design methods & $\begin{array}{l}\text { Processes and methods of game development (for example playtesting or play-centric design) help game } \\
\text { designers at implementing the gamification }\end{array}$ \\
\hline
\end{tabular}

Source: authors' elaboration on the basis of (Deterding et al., 2011, p. 12; Morschheuser, 2013). 
For the user, the effect of game design elements is limited to the first two levels only (interface elements, game mechanics). For gamification designers, on the other hand, the methods and the game model are of initial interest, followed by game design principles, which constitute the core of a successful game design, and then by the mechanics and interface elements. The gamification designers are therefore meant to read the table from bottom to top (Morschheuser, 2013).

\subsection{Player motivation AND Classifica- TION}

To develop an effective gamification strategy, understanding what motivates people is essential. Generally speaking, intrinsic motivation is distinguished from extrinsic motivation. Intrinsic motivation describes the own and inner drive of an individual. In contrast, extrinsic motivation describes external stimuli like money, trophies, social recognition or commendation (Matallaoui et al., 2017, p. 12).

In the development of gamified systems, intrinsic motivation (for example achievement or status) as well as extrinsic motivation (for example rank, points, leaderboards and badges) should be addressed (Kapp et al., 2014, p. 239). In this way, a player receives important and positive feedback for his/her activities, which may motivate him/her to learn or study (Fernandes, 2016). That feedback is crucial for motivation, and the emergence of an ideal condition referred to as flow (Sailer, 2016, p. 31).

The flow theory can be traced back to psychologist Mihaly Csikszentmihalyi (1975) and describes the ideal state between the anxiety of being overcharged and boredom as a result of not being challenged enough. In this condition, players are so immersed in an activity that nothing else is of importance to them (Csikszentmihalyi, 1975, pp. 49-54). Csikszentmihalyi furthermore differentiates several characteristics of the flow. In particular, game designers have to take account of characteristics which are responsible for motivation and engagement. These are the design of challenging tasks, the definition of clear goals and giving feedback to the player (Matallaoui et al., 2017, pp. 14-15). To find the ideal point, game designers have to create an elaborate interaction between the system and the player, and monitor this interaction via constant feedback loops (Zichermann \& Cunningham, 2011, p. 17). In that respect, it must be considered that there are different archetypes of players which can be addressed through individual forms of motivation (Matallaoui et al., 2017, p. 2).

One of the most established theories for classification of player types goes back to Richard Bartle. He studied the behaviour of video game players and was able to group them into four categories:

- killers who value competition against other players, victory is their goal,

- achievers who like clear rules and goals, want to collect points and level up, want to be the best or the first,

- socialisers who use games to connect socially or to interact, the community is their goal,

- explorers who want to explore the rules, ideal strategies, mechanisms and secrets of the game (Bartle, 2003, pp. 162-166).

However, no player can exclusively be put into one category. In fact, shares of all four categories can be found in every player. For implementing a successful gamification, the application should consider and serve all four categories, if that is possible (Zichermann \& Cunningham, 2011, pp. 21-24).

\subsection{APPLICATION OF GAMIFICATION IN TOUR- ISM}

The idea of applying gamification in tourism has found acceptance in both literature and practice. One of the earlier works on the topic, by Nicholson (2012), is focused on science and other participatory museums which, according to him, "provide models for both real-world and digital gamification environments". It promotes the concept of "meaningful gamification" which enables participants to "find meaning in a real-world activity, which can then lead to building up internal motivation to engage with that activity".

$\mathrm{Xu}$ et al. (2017) identify six areas in which, according to them, gamification can benefit tourism, which include "raise brand awareness", "enhance tourist experiences", "engagement", "improve customer loyalty", "entertainment" and "employee management", and provide several examples illustrating such applications (though some of them seem related rather to games than gamification).

A more comprehensive overview of tourism gamification is provided by Negruşa et al. (2015) who investigate it in the context of sustainability, noting the links between these two concepts. They distinguish three types of sustainable gamification effects (economic, social and environmental) and provide 
their real-world-based examples for three types of relationships: tourism organisation - tourist (exemplary objective: higher consumption frequency), tourism organisation - employee (exemplary objective: increase productivity levels) and tourism organisation - community (exemplary objective: save energy and reduce waste).

While the two sources mentioned above report on and classify the various examples of the application of gamification to tourism, there is also literature on how to apply gamification to tourism. The most important work in this vein is by Bulencer and Egger (2015) who provide the Memorable Experience Design framework combining design process and properties with theories, tools and techniques related to gamification and experience design.

Apart from the pragmatic view of tourism gamification, some implications of more theoretical nature were drawn in the literature. One notable example is the paper by Loong (2014) which proposes and interrogates the ontological assumption that tourism is being gamified, considers the blurring of boundaries between representation and reality, and its significance in tourism, as well as outlines an adequate methodological framework.

\section{RESEARCH METHODS}

The chosen approach adopts the concepts originally defined and developed in the context of design patterns for gamification of work (Swacha \& Muszyńska, 2016). While the techniques described in the following section neither adopt nor implement the work gamification design patterns, both the name/context/problem/solution scheme for their definition and what/when-where/how/why scheme for their classification are followed. Therefore, each technique is classified into one of the following four types:

- affecting what a tourist does,

- affecting when or where a tourist does what he/ she does,

- affecting how a tourist does what he/she does,

- affecting why a tourist does what he/she does,

and described using the following four fields:

- the name, assigned to techniques with care to make them descriptive,

- the context for its usage, describing a situation which deserves attention and possible application of certain gamification technique,
- the problem, which is the actual goal that is to be achieved by applying gamification - the apparent shift of terms is intentional, as what is a solution to a tourist-related issue (forming the context) becomes itself a problem for the gamification designer,

- the solution, which describes how the problem can be solved using game-inspired techniques.

Regarding the tourist attraction visiting process, it is considered in its wide definition as consisting of the three phases identified by Staab et al. (2012) in the context of tourism consumer life cycle, that is: before trip, on site and after trip. For this reason, the following three sections describe gamification techniques suitable for the respective phases of the visiting process.

\section{TECHNIQUES APPLICABLE BEFORE A TRIP}

The first phase of the tourist attraction visiting process, the core element of which is a trip planning, is of key importance from the point of view of a tourism attraction manager, as it is decided in this phase whether a tourist will actually make a visit, where he/ she will do so and when.

The gamification can be used to attract a tourist by increasing his or her interest in visiting by posing a challenge and promising a reward. Tab. 2 lists four types of challenges specific for the before-trip phase. Notice that all the proposed solutions there require the gamification system to be accessible before the visit.

\section{TECHNIQUES APPLICABLE ON SITE}

It is during the second phase of the tourist attraction visiting process that the core visitor experience is formed. A positive visitor experience is a result of several factors, and a tourist attraction manager can have an impact on only a part of them. Gamification can raise the level of visitor satisfaction by instilling him or her with three types of effects (Herger, 2014):

- aah-effect - a feeling of surprise mingled with admiration that could be caused by something 
Tab. 2. Techniques applicable in the before-trip phase of the visiting process

\begin{tabular}{|c|c|c|c|}
\hline $\begin{array}{l}\text { NAME } \\
\text { (TYPE) }\end{array}$ & CONTEXT & PROBLEM & SOLUTION \\
\hline $\begin{array}{l}\text { Challenge of visit } \\
\text { (what) }\end{array}$ & few tourists visit a tourism attraction & attract visitors & $\begin{array}{l}\text { reward coming with points, badges } \\
\text { and/or collectibles }\end{array}$ \\
\hline $\begin{array}{l}\text { Challenge of place } \\
\text { and time } \\
\text { (when-where) }\end{array}$ & $\begin{array}{l}\text { - an event is planned with little interest } \\
\text { from tourists, } \\
\text { - the attraction is overcrowded in rush } \\
\text { hours and lacks visitors in the morning } \\
\text { and/or evening hours }\end{array}$ & $\begin{array}{l}\text { attract visitors } \\
\text { to a given place } \\
\text { and time }\end{array}$ & $\begin{array}{l}\text { reward attending an event (or, more } \\
\text { generally an attraction at a certain time) } \\
\text { with bonus points, badges } \\
\text { and/or collectibles }\end{array}$ \\
\hline $\begin{array}{l}\text { Challenge of public } \\
\text { transit } \\
\text { (how) }\end{array}$ & most tourists come by car & $\begin{array}{l}\text { parking is } \\
\text { overcrowded }\end{array}$ & $\begin{array}{l}\text { reward coming by public transit } \\
\text { with bonus points, badges } \\
\text { and/or collectibles }\end{array}$ \\
\hline $\begin{array}{l}\text { Challenge of exhibit } \\
\text { (why) }\end{array}$ & $\begin{array}{l}\text { - tourists see little reason to visit } \\
\text { an attraction, } \\
\text { - tourists do not recognise the value } \\
\text { of an exhibit }\end{array}$ & $\begin{array}{l}\text { make visitors } \\
\text { interested } \\
\text { in a particular } \\
\text { exhibit }\end{array}$ & $\begin{array}{l}\text { make seeing an exhibit a part } \\
\text { of a longer quest completing which is } \\
\text { rewarded with points, badges } \\
\text { and/or collectibles }\end{array}$ \\
\hline
\end{tabular}

Tab. 3. Techniques applicable in the on-site phase of the visiting process

\begin{tabular}{|c|c|c|c|}
\hline $\begin{array}{l}\text { NAME } \\
\text { (TYPE) }\end{array}$ & CONTEXT & Problem & SOLUTION \\
\hline $\begin{array}{l}\text { Story } \\
\text { (what) }\end{array}$ & $\begin{array}{l}\text { some tourists may not see } \\
\text { the general idea behind } \\
\text { the exhibits or may not link } \\
\text { various exhibits with each } \\
\text { other }\end{array}$ & $\begin{array}{l}\text { make visitors aware } \\
\text { of the root idea and let } \\
\text { them immerse in the world } \\
\text { of exhibition }\end{array}$ & $\begin{array}{l}\text { present a story providing a historical background, } \\
\text { putting exhibits in proper context and linking them } \\
\text { into a consistent whole; the story should be } \\
\text { presented by a host, a fictional or historical figure } \\
\text { related to the site or exhibition }\end{array}$ \\
\hline $\begin{array}{l}\text { Completion } \\
\text { (when-where) }\end{array}$ & $\begin{array}{l}\text { - the visitors only visit part } \\
\text { of the attraction, } \\
\text { - some exhibitions are } \\
\text { overcrowded and others } \\
\text { lack visitors }\end{array}$ & $\begin{array}{l}\text { direct visitors to less } \\
\text { attractive exhibitions }\end{array}$ & $\begin{array}{l}\text { define sets of exhibits (mixing popular and } \\
\text { unpopular ones), reward seeing all of the exhibits in } \\
\text { a set on the same day with bonus points, badges } \\
\text { and/or collectibles }\end{array}$ \\
\hline $\begin{array}{l}\text { Puzzles } \\
\text { (how) }\end{array}$ & $\begin{array}{l}\text { the visitors quickly pass by } \\
\text { exhibits, ignoring their } \\
\text { interesting properties or } \\
\text { history }\end{array}$ & $\begin{array}{l}\text { make visitors get } \\
\text { the maximum impression } \\
\text { and information about } \\
\text { exhibits }\end{array}$ & $\begin{array}{l}\text { present visitors with trivia, riddles or puzzles whose } \\
\text { solving requires close examination of an exhibit } \\
\text { or a moment of thought about it }\end{array}$ \\
\hline $\begin{array}{l}\text { Collector } \\
\text { (why) }\end{array}$ & $\begin{array}{l}\text { some tourists may find } \\
\text { the tourism attraction boring }\end{array}$ & $\begin{array}{l}\text { involve visitors in a game, } \\
\text { making them interested } \\
\text { during their full visit time }\end{array}$ & $\begin{array}{l}\text { the universal collector game scheme is to find items } \\
\text { hidden in exhibits; the goal of such game could be to } \\
\text { find a treasure, rescue a princess or solve a mystery }\end{array}$ \\
\hline
\end{tabular}

beautiful, unexpected, unfamiliar, or inexplica-

ble,

- aha-effect - typically felt when solving a puzzle or finally understanding a complex process or system,

- haha-effect - a spontaneous expression of amusement.

Tab. 3 lists four gamification techniques specific to the on-site phase.

\section{TECHNIQUES APPLICABLE AFTER A TRIP}

The third and last phase of the tourist attraction visiting process impacts how tourists would remember their visits and whether or how often they would make another visit. The gamification can be used both to reinforce memories of previous visits and to provide reasons for next visits. Tab. 4 lists four gamification techniques specific for the after-trip phase. 
Tab. 4. Techniques applicable in the after-trip phase of the visiting process

\begin{tabular}{|c|c|c|c|}
\hline $\begin{array}{l}\text { NAME } \\
\text { (TYPE) }\end{array}$ & CONTEXT & Problem & SOLUTION \\
\hline $\begin{array}{l}\text { Quest } \\
\text { (what) }\end{array}$ & $\begin{array}{l}\text { some tourists may not see } \\
\text { a reason to visit attractions } \\
\text { similar to the ones they } \\
\text { already visited }\end{array}$ & $\begin{array}{l}\text { make visitors interested in } \\
\text { visiting attractions similar } \\
\text { to the ones they already } \\
\text { visited }\end{array}$ & $\begin{array}{l}\text { - provide a story-based quest giving reasons to see } \\
\text { other similar attractions (for example, visit all } \\
\text { castles in an area), } \\
\text { - reward completing a quest with points, badges } \\
\text { and/or collectibles }\end{array}$ \\
\hline $\begin{array}{l}\text { Achievements } \\
\text { (when-where) }\end{array}$ & $\begin{array}{l}\text { - visitors do not come at } \\
\text { early or late hours, } \\
\text { - visitors do not come to } \\
\text { some attractions }\end{array}$ & $\begin{array}{l}\text { give visitors reasons to } \\
\text { come at unpopular hours } \\
\text { or to unpopular places }\end{array}$ & $\begin{array}{l}\text { - define achievements such as visiting early or com- } \\
\text { ing to less-known attractions, } \\
\text { - reward achievements with points, badges } \\
\text { and/or collectibles }\end{array}$ \\
\hline $\begin{array}{l}\text { Streaks } \\
\text { (how) }\end{array}$ & $\begin{array}{l}\text { tourists make only irregular } \\
\text { visits }\end{array}$ & $\begin{array}{l}\text { instil a habit of periodic } \\
\text { visits among visitors }\end{array}$ & $\begin{array}{l}\text { - count weeks or months with at least one visit } \\
\text { (a streak), } \\
\text { - reward long streaks with points, badges } \\
\text { and/or collectibles }\end{array}$ \\
\hline $\begin{array}{l}\text { Progress } \\
\text { (why) }\end{array}$ & $\begin{array}{l}\text { - tourists do not see their } \\
\text { visits as a continued } \\
\text { experience, } \\
\text { - tourists forget about their } \\
\text { past visits }\end{array}$ & $\begin{array}{l}\text { make visitors feel that } \\
\text { every visit counts }\end{array}$ & $\begin{array}{l}\text { - define visitor level increasing with points, } \\
\text { - provide visitors with information on where they } \\
\text { have been to, what level they are on, how many } \\
\text { points they have or what badges they have col- } \\
\text { lected so far, } \\
\text { - provide visitors with progress bars showing how far } \\
\text { they are from levelling up or getting a badge, } \\
\text { - present leaderboards showing who is doing best } \\
\text { (highest level, most points, most badges), } \\
\text { - give discounts or souvenirs for the leaders }\end{array}$ \\
\hline
\end{tabular}

Notice that all the proposed solutions there require the gamification system to be accessible after the visit.

\section{CONCLUSIONS}

Gamification has already made its entrance into tourism. It has already been applied to improve three types of relationships: between tourism organisation and tourist, between tourism organisation and employee, and between tourism organisation and community.

This paper addresses the first of the mentioned, presenting a selection of gamification techniques for enhancing the tourist attraction visiting process. For each of the three phases of the visiting process (before trip, on site and after trip), four types of problems were addressed, corresponding respectively to an intended change in:

- when and where they go,

- how they make their visits,

- and what motivates them to make a visit and see the exhibits.
An interesting and weighty observation coming from Tab. 2 and 4 is that all the solutions proposed there require the gamification to both precede and last beyond the time spent on the visited site. It can be easily achieved only if the gamification system encompasses more than one tourist attraction.

The scope of the paper is limited to the choice of techniques adequate to the identified situations that can happen during the visiting process. While the effectiveness of the proposed techniques can only be backed now with the successful application of similar techniques in other areas of life and economy (Chou, 2015), it is an interesting scientific problem for future work to verify their effectiveness based on data from real-world implementations. A good opportunity for such work emerges from completing the BalticMuseums: Love IT! Project on which both authors collaborate (BalticMuseums, 2017).

Another vein of future research based on realworld-based implementation should be to extend both the list of the proposed techniques (with new ones, possibly addressing other kinds of problems) and the description of each of the proposed techniques (with implementation guidelines, application examples and notes on observed consequences). 


\section{LITERATURE}

Adamou, B. (2011). McDonald's: The Masters of Gamification. Research Access. Retrieved from http:// researchaccess.com $/ 2011 / 08 /$ mcdonald $\%$ E2\% $80 \%$ 99s-the-masters-of-gamification/

BalticMuseums. (2017). BalticMuseums: Love IT! [Project Website]. Retrieved from http://bmloveit.usz.edu.pl

Bartle, R. A. (2003). Designing Virtual Worlds. Indianapolis, USA: New Riders.

Bulencer, P., \& Egger, R. (2015). Gamification in Tourism, designing memorable experiences. Norderstedt, Germany: Books on Demand.

Caillois, R. (2001). Man, Play and Games. Urbana, \& Chicago, USA: University of Illinois Press.

Chou, Y.-K. (2015). A Comprehensive List of 90+ Gamification Cases with ROI Stats. Retrieved from http:// yukaichou.com/gamification-examples/gamification-stats-figures/\#.VzCedYSLSUk

Csikszentmihalyi, M. (1975). Beyond Boredom and Anxiety. San Francisco, USA: Jossey-Bass.

Deterding, S., Dixon, D., Rilla, K., \& Lennart, N. (2011). From Game Design Elements to Gamefulness: Defining "Gamification". Proceedings of the 15th International Academic MindTrek Conference: Envisioning Future Media Environment, 9-15. doi: 10.1145/2181037.2181040

Fernandes, L. (2016). Gamification: applying psychology to digital transformation. Retrieved from http://www. louellafernandes.com/2016/11/28/gamification-digital-transformation/

Herger, M. (2014). Enterprise Gamification. Engaging People by Letting Them Have Fun. Book 1. The Basics. Luxembourg: CreateSpace.

Kapp, K. M., Blair, L., \& Mesch, R. (2014). The Gamification of Learning and Instruction Fieldbook: Ideas into Practice. San Francisco, USA: Wiley.

Loong, B. L. S. (2014). Tourism and Simulacrum: The Computational Economy of Algorithmic Destinations. Procedia - Social and Behavioral Sciences, 144, 237-246. doi: 10.1016/j.sbspro.2014.07.292

Matallaoui, A., Hanner, N., \& Zarnek, R. (2017). Introduction to Gamification: Foundation and Underlying Theories. In S. Stieglitz, C. Lattemann, S. Robra-Bissantz, R. Zarnekow, T. Brockmann (Eds.), Gamification: Using Game Elements in Serious Contexts (pp. 3-17). Cham, Switzerland: Springer International.

McGonigal, J. (2010). Gaming can make a better world [Video File]. TED Talks. Retrieved from https:// www.ted.com/talks/jane_mcgonigal_gaming_can_ make_a_better_world

Morschheuser, B. (2013). Game-Design Elemente, Grundsätze und Methoden [Game design elements, fundamentals and methods]. Gamifinator. Retrieved from http://gamifinator.de/2013/01/game-design-elemente-grundsatze-und-methoden/
Negruşa, A., Toader, V., Sofică, A., Tutunea, M., \& Rus, R. (2015). Exploring Gamification Techniques and Applications for Sustainable Tourism. Sustainability, 7(8), 11160-11189. doi: 10.3390/su70811160

Pelling, N. (2011). The (short) prehistory of "gamification"... Nanodome. Retrieved from https:// nanodome.wordpress.com/2011/08/09/the-shortprehistory-of-gamification/

Rackwitz, R. (2015). Gamification: Spielen ist keine Erfindung der Unterhaltungsindustrie. [Gamification: Playing is not an invention of the entertainment industry]. In C. Stiegler, P. Breitenbach, T. Zorbach (Eds.), New Media Culture: Mediale Phänomene der Netzkultur [New media culture: media-based phenomena of Cyberculture], (pp. 217-237). Bielefeld, Germany: Transcript.

Ruffino, P. (2014). From engagement to life, or: how to do things with gamification? In M. Fuchs, S. Fizek, P. Ruffino, N. Schrape (Eds.), Rethinking Gamification (pp. 47-71). Lüneburg, Germany: Meson.

Sailer, M. (2016). Die Wirkung von Gamification auf Motivation und Leistung: Empirische Studien im Kontext manueller Arbeitsprozesse [The impact of gamification of motivation and performance: Empirical studies in the context on manual working processes]. München, Germany: Springer.

Salen, K., \& Zimmerman, E. (2004). Rules of Play: Game Design Fundamentals. Massachusetts. USA: Massachusetts Institute of Technology.

Shauchenka, N., Ternès, A., \& Towers, I. (2014). Gamification. In I. Towers, A. Ternès (Eds.), Internationale Trends in der Markenkommunikation [International trends in brand communication], (pp. 33-51). Wiesbaden, Germany: Springer Gabler.

Stabb, S., Werther, H., Ricci, F., Zipf, A., Gretzel, U., Fesenmaier, D. R., Paris, C., \& Knoblock, C. (2002). Intelligent systems for tourism. IEEE Intelligent Systems, 17, 53-66. doi: 10.1109/MIS.2002.1134362

Swacha, J., \& Muszyńska, K. (2016). Design Patterns for Gamification of Work. In F. J. García-Peñalvo (Ed.), Proceedings TEEM'16: Fourth International Conference on Technological Ecosystems for Enhancing Multiculturality (pp. 763-770). New York, USA: ACM.

Xu, F., Buhalis, D., \& Weber, J. (2017). Serious games and the gamification of tourism. Tourism Management, 60, 244-256. doi: 10.1016/j.tourman.2016. 11.020

Zichermann, G., \& Cunningham, C. (2011). Gamification by Design. Sebastopol, USA: O’Reilly. 